\title{
Patch dynamics and response to disturbance of the seagrass Zostera novazelandica on intertidal platforms in southern New Zealand
}

\author{
Deborah L. Ramage*, David R. Schiel** \\ Marine Ecology Research Group, Zoology Department, University of Canterbury, Private Rag 4800, \\ Christchurch 1, New Zealand
}

\begin{abstract}
We examined the patch dynamics of the intertidal seagrass Zostera novazelandica on 2 reef platforms in order to understand the processes governing the establishment, maintenance and mortality of patches. The size distribution of patches at 3 tidal heights (low, mid and high shore) was assessed. Eighty patches, ranging in initial size from 0.1 to $2.4 \mathrm{~m}^{2}$ surface area, were tagged and video image analysis was used bi-monthly for 14 mo to calculate rates of expansion and contraction of these patches. Permanently marked $150 \mathrm{~m}^{2}$ areas of reef were monitored monthly to record patch recruitment and mortality. Initially, $75 \%$ of patches were $<0.5 \mathrm{~m}^{2}$ All patches decreased in size during winter, probably due to increased wave action, and expanded during spring and summer. The proportional expansion and contraction of patches was independent of initial patch size. At the end of the study the size distribution of patches was similar to the initial distribution. Patch mortality was restricted to those $<0.4 \mathrm{~m}^{2}$, of which $60 \%$ disappeared during the study. Larger patches suffered partial mortality through fragmentation. No large patches were formed through the amalgamation of smaller patches. Seedlings recruited into small sediment pockets in tidepools during spring, but few survived through summer because of removal by wave action. Experimental perturbation of patches resulted in increased erosion followed by decreased growth rates and, in many small patches, mortality. Removing only seagrass blades, however, resulted in increased production of new shoots relative to controls. Overall, seagrass patches are susceptible to disturbance, successful recruitment by seedlings may be rare or at least episodic, and populations are probably long-lived and depend on slow vegetative growth for maintenance and expansion.
\end{abstract}

KEY WORDS: Seagrass - Patch dynamics - Disturbance - Zostera novazelandica Intertidal New Zealand

\section{INTRODUCTION}

The study of patch dynamics has been widely used in population and community ecology to provide insights into population dynamics and persistence, community structure, and stability (Wu \& Levin 1994, Bell et al. 1995). Patches and patch-forming mechanisms operate on distinct spatial and temporal scales controlled by a variety of intrinsic and extrinsic factors

- Present address. Zoology Department, University of Queensland, Queensland 4072, Australia

- Addressee for correspondence.

E-mail: d.schiel@zool.canterbury.ac.nz
(Levin \& Paine 1974, Wu \& Levin 1994). A community can be viewed as a mosaic of 'patches' which are part of an integrated system. The term 'patch' implies a discrete, internally homogeneous unit that is closed to its surroundings (Kotliar \& Wiens 1990). In nature, patches are rarely isolated from their surroundings and vary widely in size, shape and persistence (Levin \& Paine 1974, Kotliar \& Wiens 1990, Steele et al. 1993). Disturbance acts to increase environmental heterogeneity by interrupting the natural sequence of succession and by destabilising established equilibria (Steele et al. 1993).

Seagrass communities are dynamic on several spatial and temporal scales (den Hartog 1970). Changes 
in community structure have been documented (Clarke \& Kirkman 1989), but an understanding of the patterns of distribution and abundance of seagrasses is hampered by relatively sparse data on vegetative and reproductive dynamics. Only recently, compared to other subtidal and intertidal communities (Paine 1979, Paine \& Levin 1981, Sousa 1984, Turner 1985), has a more quantitative approach to seagrass ecology emerged.

Seagrass populations undergo extensive seasonal fluctuations due to variable growth conditions and catastrophic declines during storm events and epidemic diseases (den Hartog 1970, Olesen \& Sand-Jensen $1994 \mathrm{a}, \mathrm{b}$ ). Perturbations in seagrass communities have resulted from pollution (Cambridge \& McComb 1984), erosion (Kirkman 1978) and storm activity which vary considerably in scale (Clarke \& Kirkman 1989). Northern hemisphere populations have suffered severely reduced abundances due to increased coastal development and anthropogenic eutrophication, and other environmental changes (McComb et al. 1981, Short \& Wyllie-Echeverria 1996, Marbà et al. 1996a). Although decline has occurred almost worldwide (Cambridge 1975, Kemp et al. 1983, Larkum \& West 1983, Cambridge \& McComb 1984), studies of the dynamics of seagrass cover and the associated colonisation, expansion, recession and mortality processes are few. Individual seagrass plants seem able to withstand considerable stress, but the stability of meadows can still be greatly affected by environmental changes (McComb et al. 1981). In temperate ecosystems, erosional cycles determined by wind direction, wave and tidal height lead to spatial and temporal changes in seagrass distribution (Fonseca et al. 1983, Fonseca \& Kenworthy 1987).

The seagrass Zostera novazelandica is endemic to New Zealand and occurs only in the intertidal zone. Although it is common in large estuaries, especially along tidal channels, it also occurs on rocky intertidal platforms along the eastern coast of the South Island, where patches are interspersed among algal beds (cf. Woods \& Schiel 1997). Reproduction occurs during summer and seedlings can be found in sediments in rock pools and tidal cracks during late autumn (Ramage \& Schiel 1998). These intertidal platforms are accessible to the public, and fragmentation of seagrass patches after heavy pedestrian traffic has been observed. Our study was prompted by the fact that virtually nothing was known about the population dynamics of this important intertidal species and that its resilience to disturbance will be a major factor in managing human impacts. Here we measure growth and survival of seagrass patches and test their responses to 2 forms of disturbance, to the patches themselves and to the seagrass blades.

\section{MATERIALS AND METHODS}

Study sites. Patches of Zostera novazelandica were studied from January 1994 to March 1995 at 2 sites on the Kaikoura Peninsula, on the east coast of the South Island of New Zealand $\left(42^{\circ} 25^{\prime} \mathrm{S}, 173^{\circ} 42^{\prime} \mathrm{E}\right.$; Fig. 1). Wairepo Flats is a semi-protected siltstone reef that is generally sheltered from large swells but is occasionally exposed to severe wave conditions. Mudstone Bay is also a semi-protected siltstone reef protected by the peninsula and the coastline but occasionally exposed to southerly storms (cf. Hickford \& Schiel 1995, Woods \& Schiel 1997). The platforms at both sites are several hundred metres long and ca $100 \mathrm{~m}$ from the highest tide level to the 0 tide mark. The tidal range is $3.1 \mathrm{~m}$

Patch dynamics. The platforms at both sites were divided into low, mid and upper tidal zones, based on absolute tidal height and the presence of macroalgae. The lower zone had a mixed cover of several fucalean algal species, with an understory of coralline algae. The mid zone was characterised by a dominant cover of the fucalean alga Hormosira banksii, while the upper zone had virtually no macroalgae, except in tide pools and tidal cracks. The median tidal heights of these zones were 1.5 (low), 2.2 (mid) and $2.7 \mathrm{~m}$ above Chart Datum. Seagrass patches occurred in all tidal heights.

To measure the overall size distribution of seagrass patches, at least 20 transects $5 \mathrm{~m}$ wide and $30 \mathrm{~m}$ long were randomly placed at each site. The area and sediment depth of every patch encountered along transect lines were recorded. All but the smallest patches had tightly bound sediment, and rhizomes were not visible without serious disruption to patch integrity.

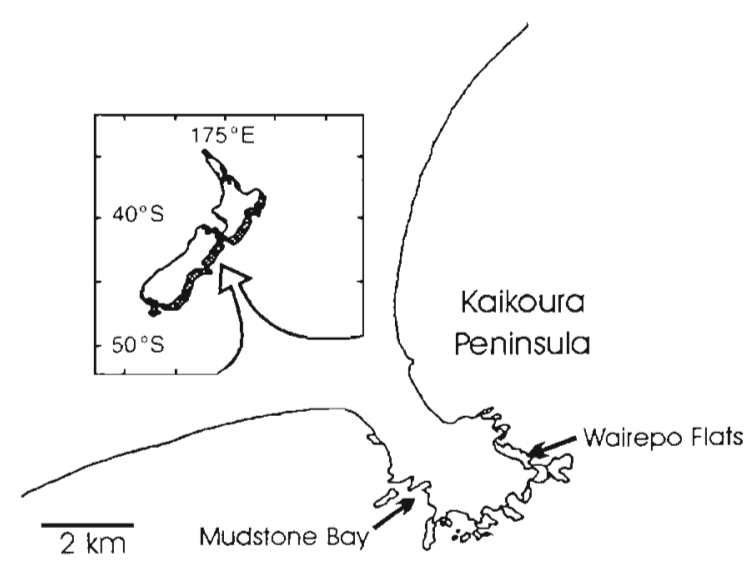

Fig. 1. Map of the Kaikoura Peninsula on the east coast of the South Island of New Zealand, showing the study sites at Wairepo Flats and Mudstone Bay 
To detect recruitment from seedlings, fragmentation or disappearance of established patches, permanently marked transects were surveyed bi-monthly. There were 10 transects $(30 \times 5 \mathrm{~m})$ at each site. These were perpendicular to the shore and ran through all tidal zones. All seagrass patches and the positions of newly established seedlings were mapped. The latter were clearly distinguishable from patch remnants because new seedlings have only a few leaves, are very shallow rooted and invariably occur in loose sediment and sand.

To measure size changes in patches through time, 50 randomly selected patches at Wairepo Flats and 30 at Mudstone Bay were permanently tagged, in the 3 tidal zones, with $1.5 \times 5 \mathrm{~cm}$ strips of plastic nailed into the reef around the patch perimeter. Each patch was videoed bimonthly from the top of a $2 \mathrm{~m}$ ladder using a Sony Hi-8 video camera. Images of each patch were then captured directly from the video onto an Apple Macintosh Quadra 700 using Rasterops Media Grabber 2.1. The images were saved as 8-bit grayscale files for analysis using Image 1.5 , a package that allowed the calculation of patch area and perimeter. These data were used to determine size-specific growth and decay rates of patches, the effect of shore height on patch growth, and differences in growth rates between seasons.

Leaf width, leaf length, and ramet densities of plants within the tagged patches were surveyed bi-monthly at each site to record changes in the vegetative characteristics of the seagrass over time. The mean leaf area index was calculated at each site by multiplying the width, length, number of leaves per ramet and ramet density (Evans 1972).

Three core samples $80 \mathrm{~mm}$ in diameter and $15 \mathrm{~cm}$ deep were extracted from large meadows at each site at bi-monthly intervals. Plant material was removed from the sediment using a sieve and divided into above-ground and below-ground components. Each portion was then dried separately in an oven at $105^{\circ} \mathrm{C}$ for $24 \mathrm{~h}$, and weighed (Young \& Kirkman 1975, Dawson 1976, Larkum et al. 1984, Vermaat et al. 1993).

Patch disturbance. During the summer of 1993-94 examination of the patches at Wairepo Flats indicated there may be within-patch patterns of expansion and contraction. Healthy new growth appeared to be restricted to the landward sides of patches or into tidepools, while the seaward sides were generally devoid of shoots and the rhizome mat was partially exposed. Consequently, we posed the null hypothesis that the recovery of a patch is independent of which side is disturbed and that the effects of disturbance are independent of initial patch size. This was tested experimentally by using 2 disturbance regimes, removing $25 \%$ of the total patch area from either the seaward or landward side of patches. We also tested the null hypothesis that loss of seagrass blades has no effect on patch expansion or contraction. To test this, leaf blades were trimmed from entire patches to reduce the amount of tissue available for photosynthesis by at least $90 \%$. Ten patches were assigned to each disturbance treatment in addition to 10 control patches. Within each group of 10, 5 patches had initial areas less than $1 \mathrm{~m}^{2}$ and 5 were larger than $1 \mathrm{~m}^{2}$. Patches were tagged using the same system as above both before and after the experimental disturbance. Removal of patch area was done using a spade and small trowel to sever the rhizome mat and prise the section away to be discarded. Leaf blades were trimmed to a uniform level $(2 \mathrm{~cm})$ using a pair of household scissors. All treatments and controls were in the mid tidal zone at Wairepo Flats.

Analyses. Repeated measures analysis of variance (ANOVA) (SYSTAT 7.0) was used to test the percentage changes in patch size through time. The main factors were Site (Wairepo Flats and Mudstone Bay) and initial Patch Size (See Figs. 4 \& 5 for size categories). Because of unequal sample sizes among categories, only Sizes 1 to 6 were used in the analysis so that the design would be balanced. The repeated measures were the 7 sampling dates. Data were arcsine-transformed to stabilize variances. Multivariate $F$-values (Wilks' lambda) were used to test within-subjects effects. A similar repeated measures ANOVA was used for the patch disturbance experiment, with factors Patch Size (=2) and Disturbance Treatment (=4), measured over 6 sampling dates.

\section{RESULTS}

\section{Random transects}

The sizes of Zostera novazelandica patches on the intertidal platforms of the Kaikoura Peninsula ranged from single seedlings to $9.5 \mathrm{~m}^{2}$. The size-frequency distributions were highly skewed, with $75 \%$ of all patches being $<1 \mathrm{~m}^{2}$, and were similar at both sites (Fig. 2A,B). The mean sediment depth of patches (i.e. from the surface of the patch to the reef underneath) ranged between 34 and $137 \mathrm{~mm}$ at both sites (Fig. 3). There was a significant correlation $\left(\mathrm{r}_{40}=0.51, \mathrm{p}<0.05\right)$ between patch size and sediment depth, indicating that as patches expand laterally they also accumulate sediment, which increases in depth. Most patches were associated with tidal cracks in the reef and were therefore deeper in the middle than towards the edges.

Overall, seagrass patches covered $12 \%$ ( $\pm 6.3 \mathrm{SE}$ ), $22 \%( \pm 9.7 \mathrm{SE})$, and $13 \%( \pm 8.2)$ of the primary substratum in the low, mid and upper tidal zones, respectively, at Wairepo Flats. At Mudstone Bay, seagrass patches covered $11 \%( \pm 7.3), 21 \%( \pm 5.2)$ and $7 \%( \pm 4.7)$ of the 3 tidal zones. 


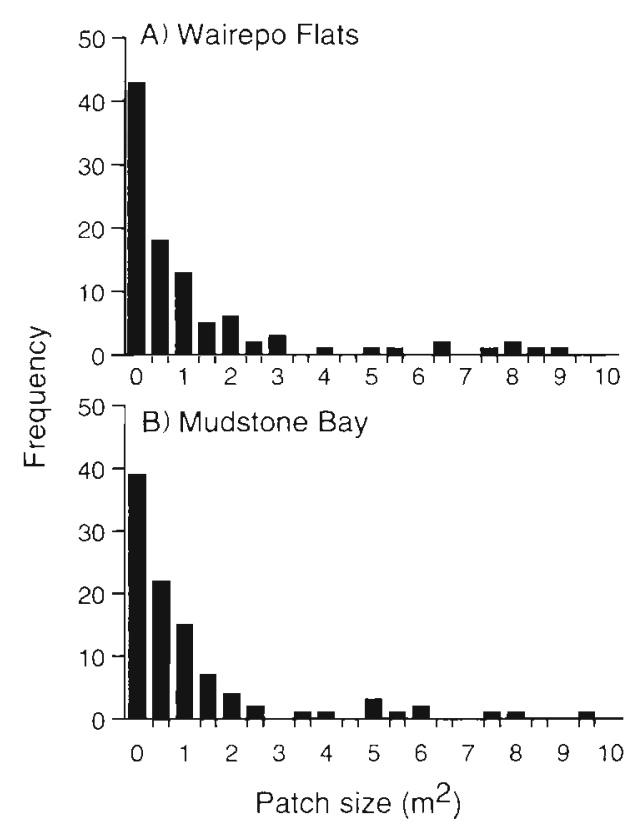

Fig. 2. Zostera novazelandica. Size frequency distribution (surface area) of patches on the reef at (A) Wairepo Flats and (B) Mudstone Bay

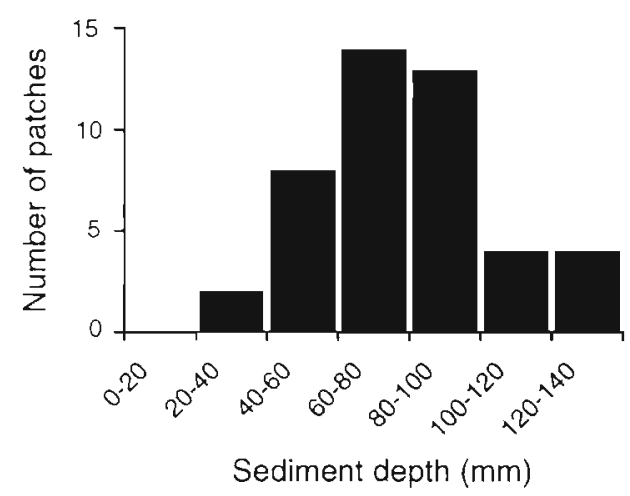

Fig. 3. Zostera novazelandica. Frequency distribution of mean sediment depth of patches at both study sites on the Kaikoura Peninsula

\section{Permanent transects}

Within the permanently marked transects at Wairepo Flats, small patches $\left(<0.4 \mathrm{~m}^{2}\right)$ were more common low on the shore than in the mid or upper intertidal zones (Fig. 4, Size Classes 1 and 2). For most of the year, there were no patches larger than $1 \mathrm{~m}^{2}$ (Size Classes >5) in the low zone. Thirteen percent of patches in the low zone were $>1 \mathrm{~m}^{2}$ in March 1994, but by winter (July) these had shrunk to $<0.8 \mathrm{~m}^{2}$ By March 1995 these did not recover to their original sizes. In the mid and upper zones, patches were more evenly spread among the size classes in March and May 1994. During winter (July to September), however, a decline in patch size resulted in a predominance of small patches $\left(<0.4 \mathrm{~m}^{2}\right)$ persisting to spring. By January 1995 many of these patches were again in the larger size classes.

In the permanently marked transects at Mudstone Bay, patches low on the shore underwent only small changes in size and fell into 2 distinct groups $(<0.4$ and 0.8 to $1.4 \mathrm{~m}^{2}$ ) throughout the year (Fig. 5). The most abundant patches in the mid and upper zones were in the smallest size category $\left(<0.2 \mathrm{~m}^{2}\right)$ throughout the year, accounting for 30 to $55 \%$ of all patches in the mid zone and $40 \%$ of those in the upper zone. There was relatively little fluctuation in patch size during winter for patches larger than $0.2 \mathrm{~m}^{2}$ (Size Classes $>1$ ) compared to Wairepo Flats patches in the same size classes. This may be due to Mudstone Bay being slightly more sheltered from oceanic swells and storms than Wairepo Flats.

New patches recruited during winter and spring (July to November) at both sites, either through fragmentation of larger patches or else through establishment of seedlings (Fig. 6A,B). Production of patches by the fragmentation of larger patches occurred mostly in the middle of winter (July) and tapered off through spring at both sites. Peak recruitment of seedlings, with an average of just over 1 per $150 \mathrm{~m}^{2}$, occurred in November at both sites. Overall, seedlings formed $40 \%$ of new recruits, while fragmentation accounted for $60 \%$

Seedlings consisted of a single ramet and were found either associated with clumps of coralline algae or in tidal cracks and pools. Because all seedlings and patches had been mapped, mortality could be accurately determined. All of the seedlings found through November (Fig. 6A,B) had disappeared by January at both sites (Fig. 6C,D). Mortality of all other patches on the permanent transects (i.e. those formed by fragmentation plus all the other mapped patches) exceeded the production rate by fragmentation during the winter months. However, mortality was low overall. An average of $<4$ small patches per $150 \mathrm{~m}^{2}$ disappeared from reefs during the year, representing $4 \%$ mortality of established patches. Overall, there was little variation in the total cover of seagrass after 1 yr, despite the fluctuations in patch sizes, recruitment and mortality throughout the year.

\section{Tagged patches}

Several general patterns were evident through time for the tagged patches (Fig. 7). Most patches became 

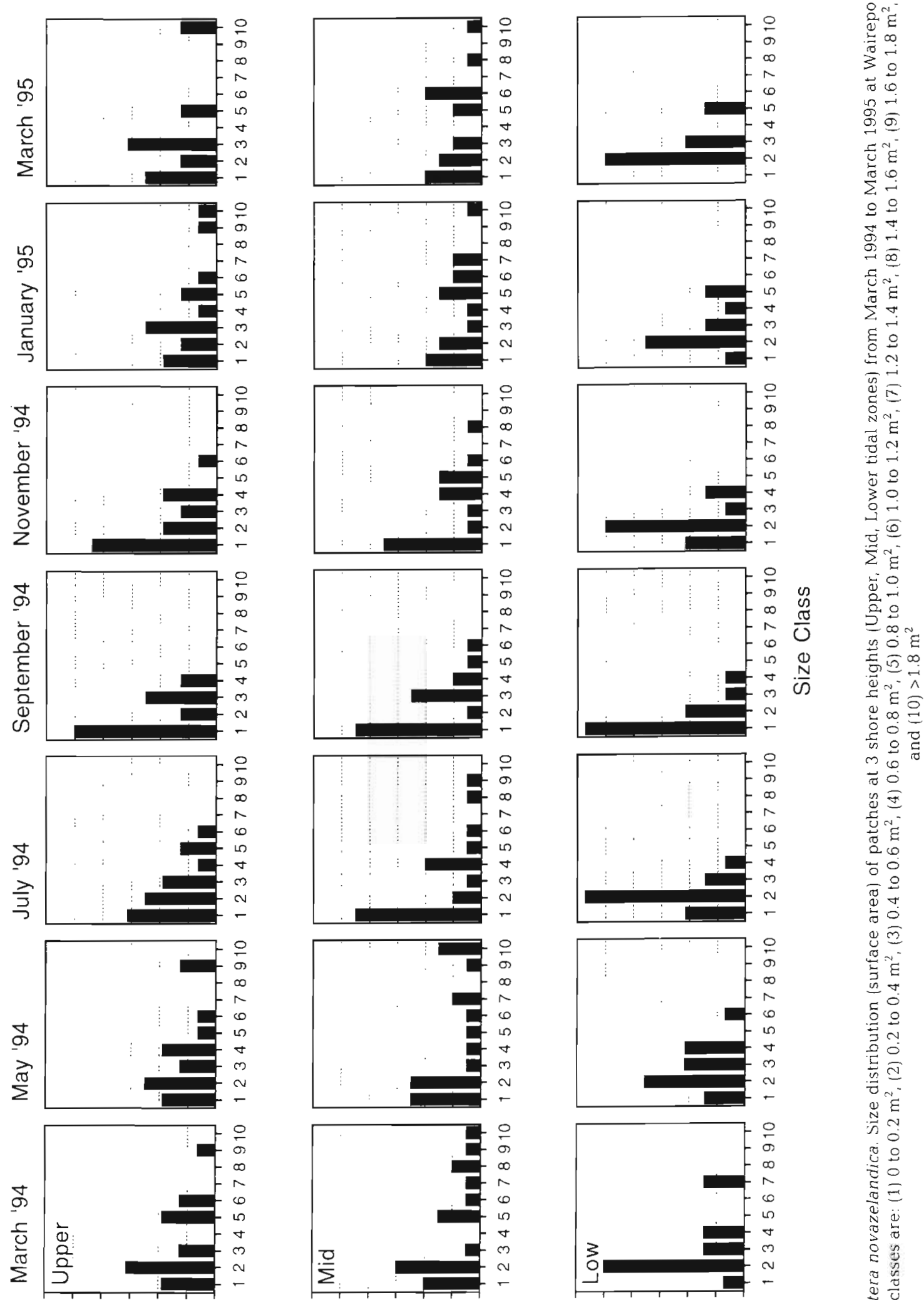

은요앙유응
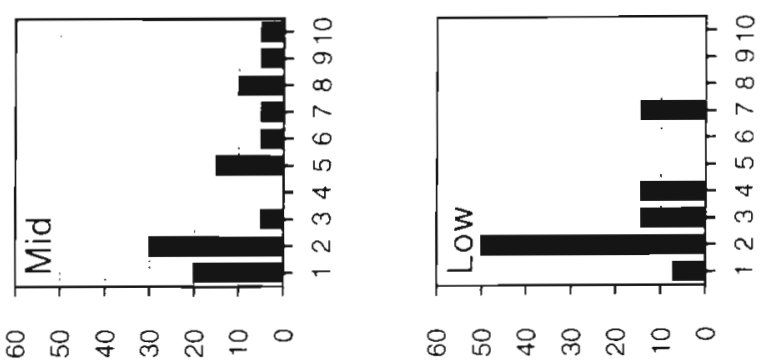

әбеұนәวлаd

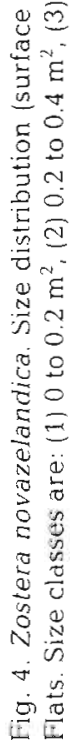



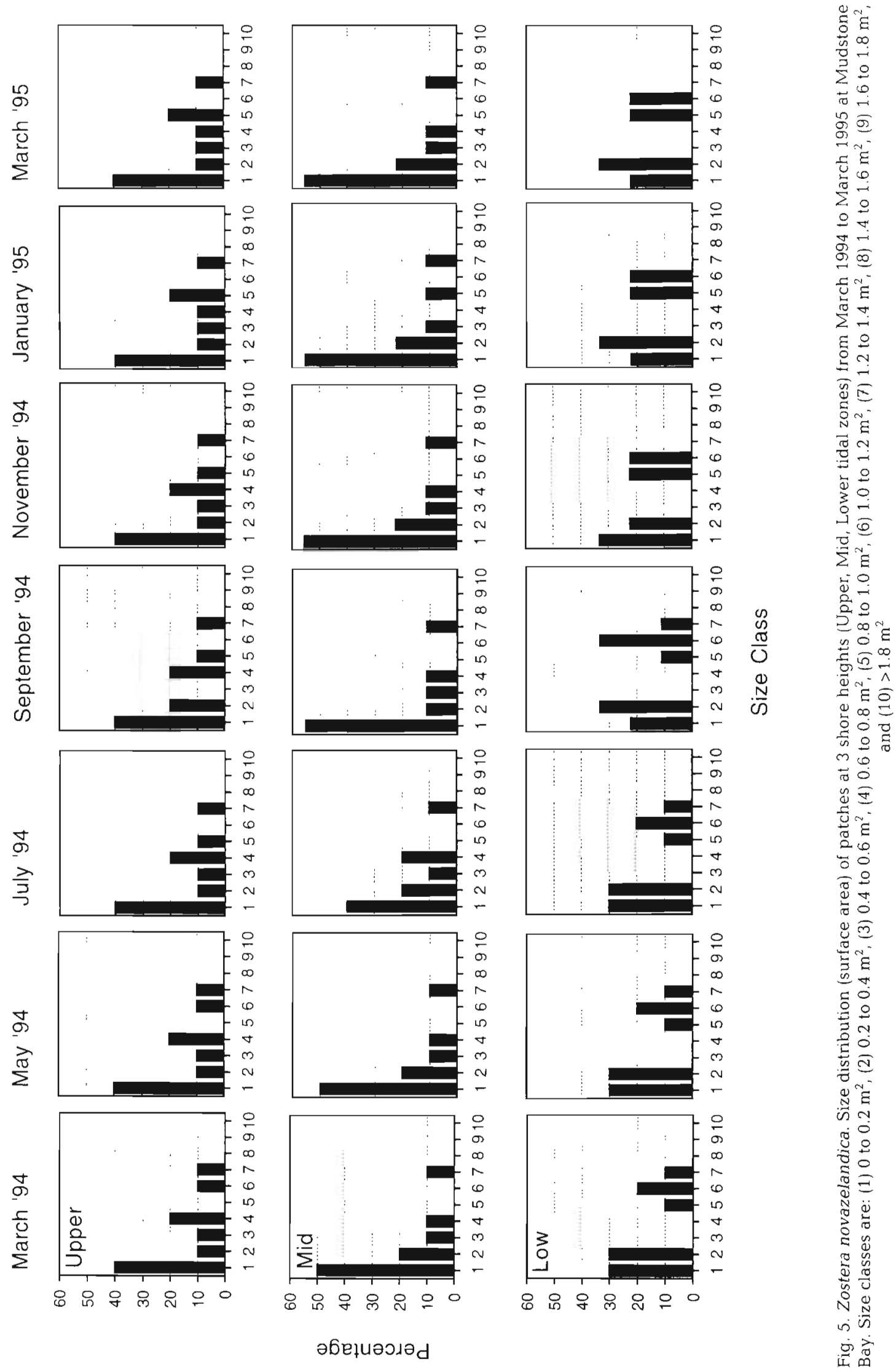

응 앙요 응

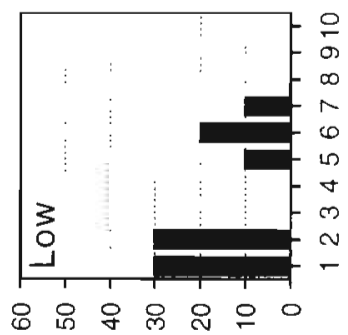

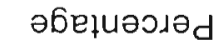

0
0
$\frac{D}{U}$
0
$\frac{N}{n}$ क⿺辶

mi

里

पू ह

$\div 0$

(5)

穴

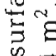

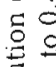

हैำ

券要

$\stackrel{8}{\mathbb{N}}$

ชู่

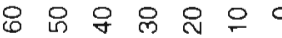



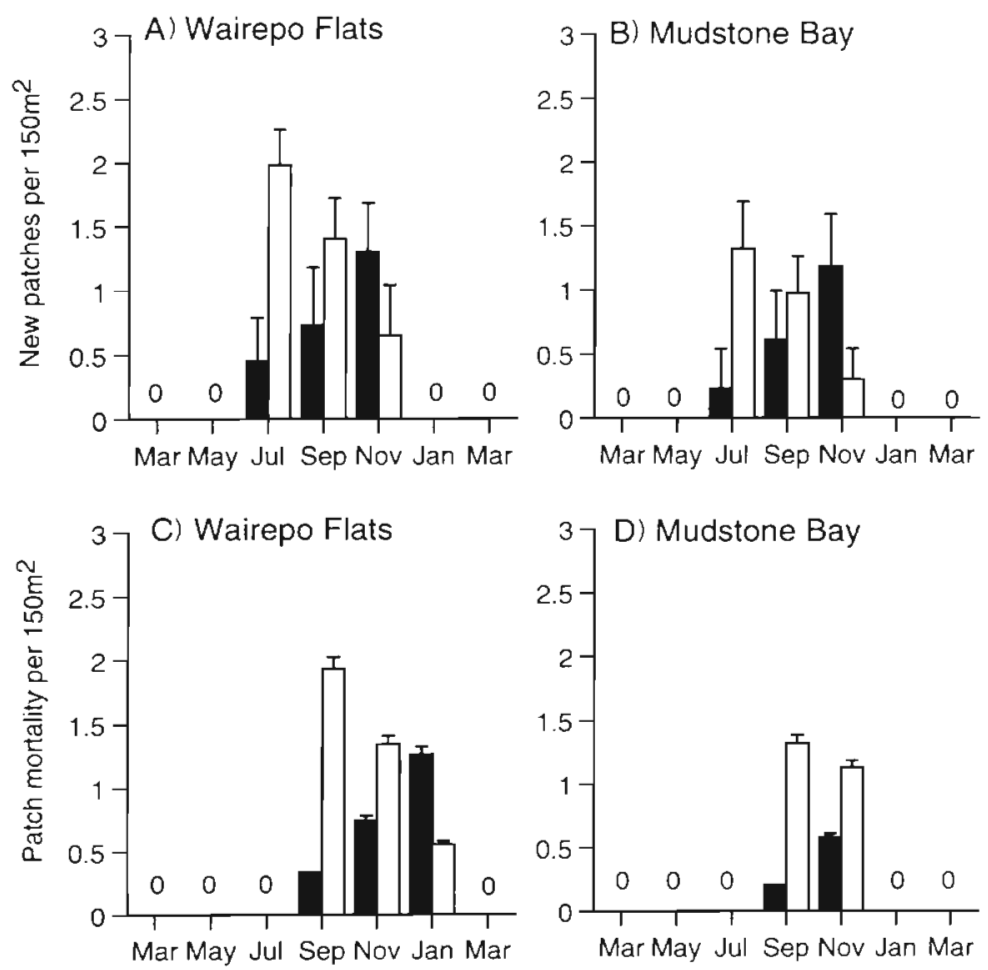

Fig. 6. Zostera novazelandica. Mean number ( $\pm 1 \mathrm{SE}$ ) of new patches per $150 \mathrm{~m}^{2}$ permanent plot each month at (A) Wairepo Flats and (B) Mudstone Bay. Open bars represent new patches formed by fragmentation of established patches; closed bars are the patches formed by seedings. Mean number $( \pm 1 \mathrm{SE})$ of patches lost per $150 \mathrm{~m}^{2}$ permanent plot each month at (C) Wairepo Flats and (D) Mudstone Bay. Open bars represent patches more than 2 mo old; closed bars are the number of newly established seedlings that subsequentlydisappeared from the reef
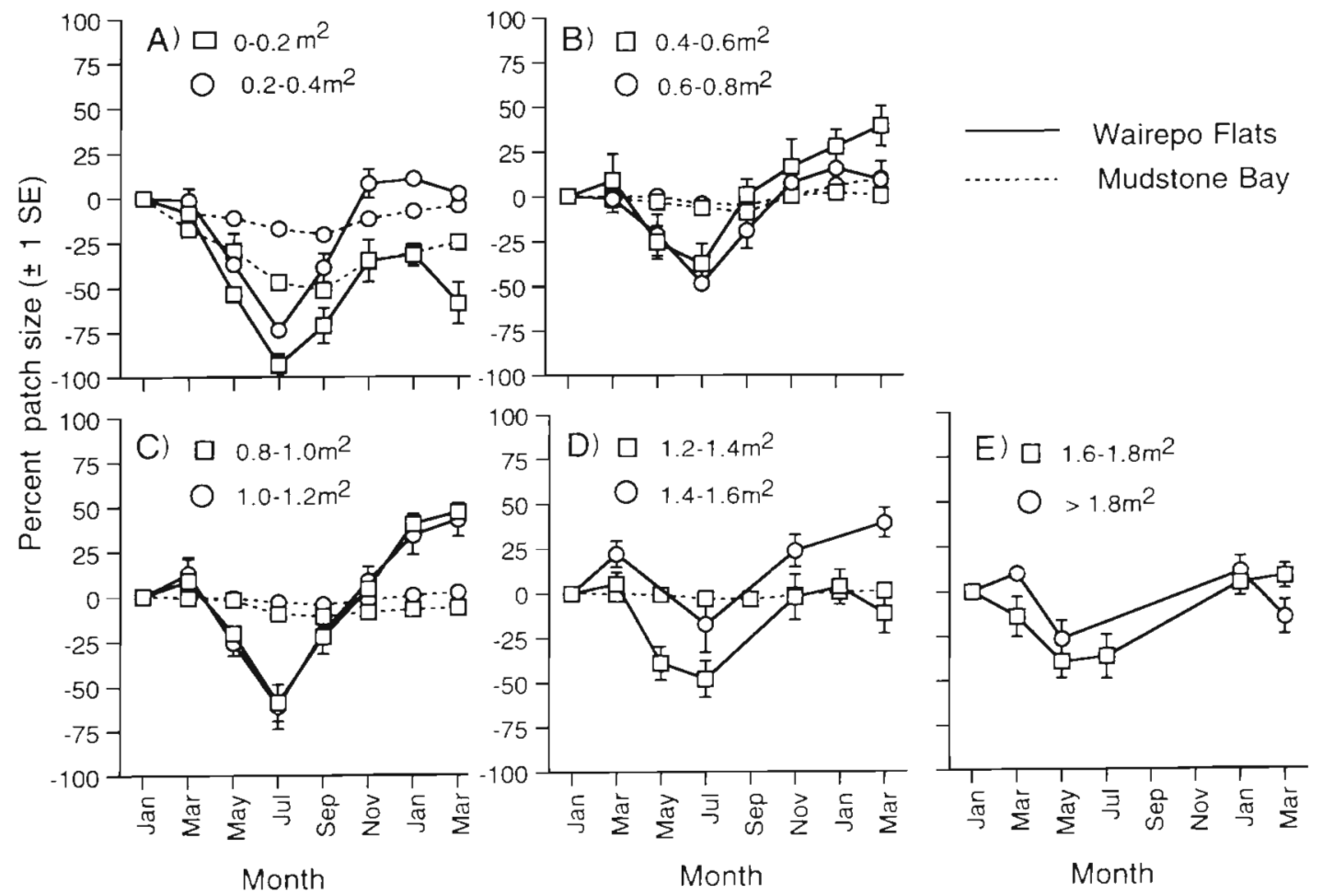

Fig. 7. Zostera novazelandica. Mean $( \pm 1 \mathrm{SE})$ percent change in patch area (relative to patch size measured during the previous sampling period) through time at Wairepo Flats and Mudstone Bay of the 10 size classes (A) 0 to $0.4 \mathrm{~m}^{2}$, (B) 0.4 to $0.8 \mathrm{~m}^{2}$, (C) 0.8 to $1.2 \mathrm{~m}^{2}$, (D) 1.2 to $1.6 \mathrm{~m}^{2}$, and (E) 1.6 to $>1.8 \mathrm{~m}^{2}$ ) 
reduced in size beginning between March and May and reached their smallest sizes in mid-winter (July), losing on average $34 \%( \pm 2.4 \mathrm{SE})$ of their initial surface area. Re-growth of patches occurred in spring and continued through the following summer. Effects were variable through time, however, and depended on both site and the initial sizes of patches. In all cases, the greatest reductions in size occurred at Wairepo Flats, probably due to the more intense wave action there compared to Mudstone Bay. Patches in the smallest size classes generally had greater percentage losses. For example, average losses at Wairepo Flats in the 2 smallest-sized patches averaged between 75 and $95 \%$ in winter (Fig. 7A). In the 0.4 to $0.8 \mathrm{~m}^{2}$ size categories (Fig. 7B), Wairepo patches lost 40 to $50 \%$ of their surface area, while Mudstone Bay patches remained the same sizes throughout the year. However, the 0.4 to $0.6 \mathrm{~m}^{2}$ patches at Wairepo were $40 \%$ larger than their initial sizes by March 1995. A similar pattern was seen in the 0.8 to $1.2 \mathrm{~m}^{2}$ size categories (Fig. $7 \mathrm{C}$ ). An average of $65 \%$ of the surface area of patches was lost during winter at Wairepo Flats, but then patches in both size categories attained a $50 \%$ increase in size by the end of summer. Similarly sized patches at Mudstone Bay showed little change. The 1.2 to $1.6 \mathrm{~m}^{2}$ size categories (Fig. 7D) showed a similar pattern, but only the 1.4 to $1.6 \mathrm{~m}^{2}$ had an overall increase by the end of summer. There were none of the largest size classes of patches at Mudstone Bay (Fig. 7E). Those at Wairepo underwent a
25 to $40 \%$ decrease in winter, and patches in the largest size class had an overall decrease over the study.

Overall, 32 of the 50 originally tagged patches (64\%) at Wairepo Flats underwent $>10 \%$ loss of surface area over the 14 mo of the study, $12(24 \%)$ grew by more than $10 \%$, while the other 6 remained about the same size. At Mudstone Bay, 12 of the 30 tagged patches $(40 \%)$ shrank in surface area by $>10 \%, 5(17 \%)$ gained $>10 \%$, and $13(43 \%)$ remained about the same size. The total surface area of seagrass on the reefs was similar at the beginning and end of the study.

The repeated measures ANOVA on patch size through time showed that proportional changes in area varied significantly among size categories $\left(F_{5,85}=4.07\right.$, $p=0.002)$ and that this did not depend on the other factors (all interaction terms involving 'size' were not significant). Changes in patch area differed among the months of sampling $\left(F_{6.80}=22.78, \mathrm{p}<0.001\right)$ but this effect varied between the 2 sites (Month $\times$ Site: $F_{6,80}=$ $12.20, p<0.001)$. We separately tested whether an association of a patch with a tidepool affected growth. Although patches with an association with a tidepool stayed approximately the same size over the study period $(+0.33 \%$ in surface area) while patches not associated with tidepools shrank by an average of $7 \%$, differences were not significant because of high variability $\left(F_{1,78}=0.42, \mathrm{p}=0.52\right)$.

Patch mortality was size dependent. Of the original tagged patches at Wairepo Flats, only those $<0.4 \mathrm{~m}^{2}$ in

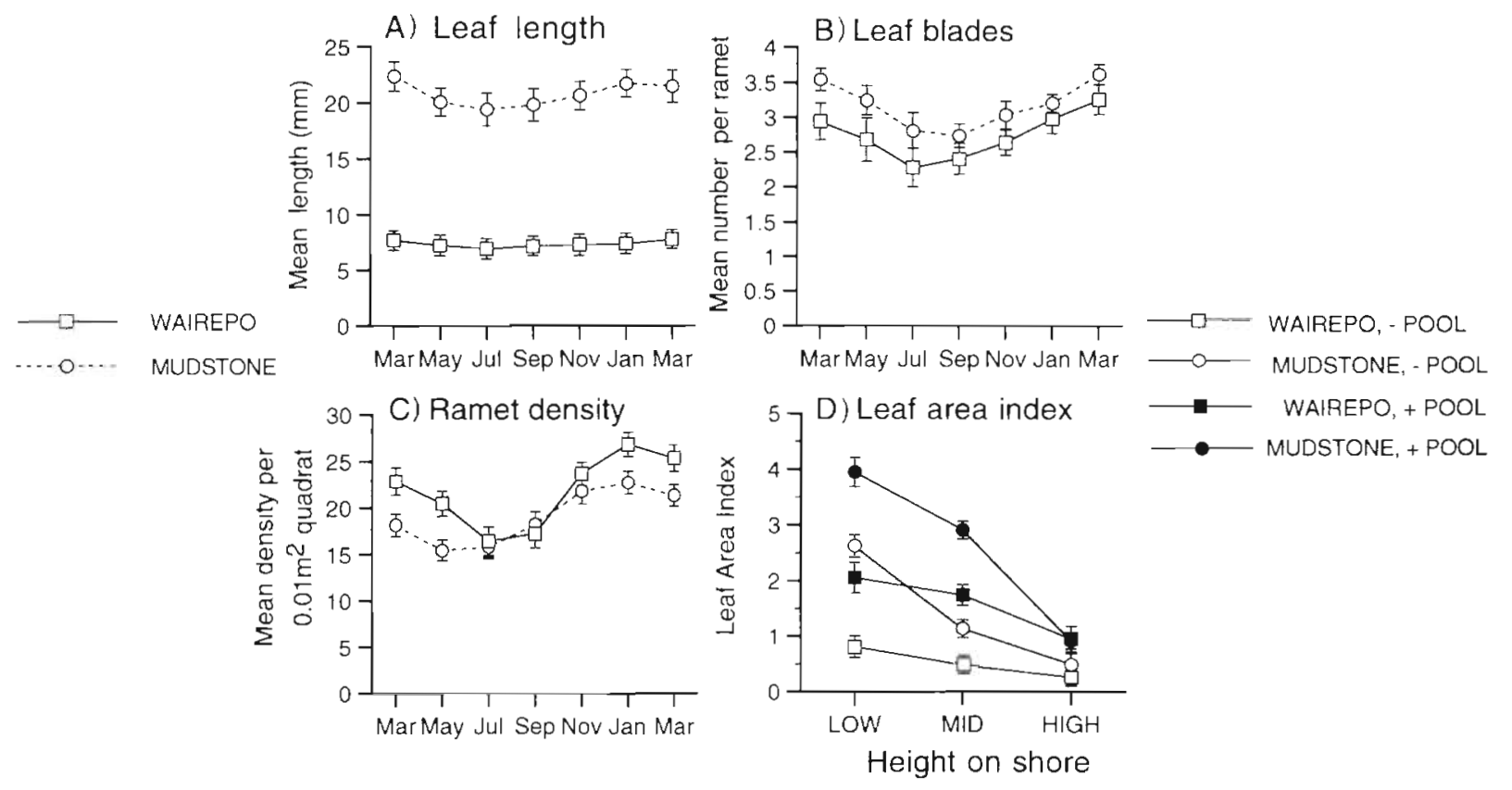

Fig. 8. Zostera novazelandica. Vegetative characteristics of plants at Wairepo Flats and Mudstone Bay through time: (A) mean $( \pm 1 \mathrm{SE})$ leaf length, (B) mean ( $\pm 1 \mathrm{SE}$ ) number of leaf blades per ramet, (C) mean ( $\pm 1 \mathrm{SE}$ ) ramet density per $0.01 \mathrm{~m}^{2}$, (D) leaf area index ( \pm 1 SE) for plants at 3 shore heights and 2 sites in patches either bordering or not bordering a tide pool 
surface area disappeared during the year. The smallest patches $\left(<0.2 \mathrm{~m}^{2}\right)$ had $50 \%$ mortality, while those in the 0.2 to $0.4 \mathrm{~m}^{2}$ category had $11 \%$ mortality.

Leaf blades of plants at Mudstone Bay were about 3 times longer than those at Wairepo Flats and there was no seasonal trend in blade length at either site (Fig. 8A). Neither the number of leaf blades per ramet (Fig. 8B) nor the ramet densities of patches (Fig. 8C) varied greatly between the 2 sites. They followed the same pattern of a winter decline and spring increase at both sites. The decline during winter may have been exacerbated by infection by the slime mould Labyrinthula, which was identified microscopically. It infected almost all of the older leaf blades, causing them to senesce and abscise, but did not seem to affect the younger leaf blades or rhizomes.

Leaf area indices calculated for both sites, 3 shore heights, and for plants associated and not associated with tidepools, were significantly different over all factors and all interactions (Site $\times$ Shore height $\times$ Tidepool interaction: $\left.F_{2,59}=11.31, \mathrm{p}<0.001\right)$. Patches on the low shore had a larger leaf area index than those in the mid or upper shore, and patches associated with tidepools had a greater index than those not associated with pools (Fig. 8D). Generally, the patches at Mudstone Bay had a greater leaf area index than those at Wairepo Flats.

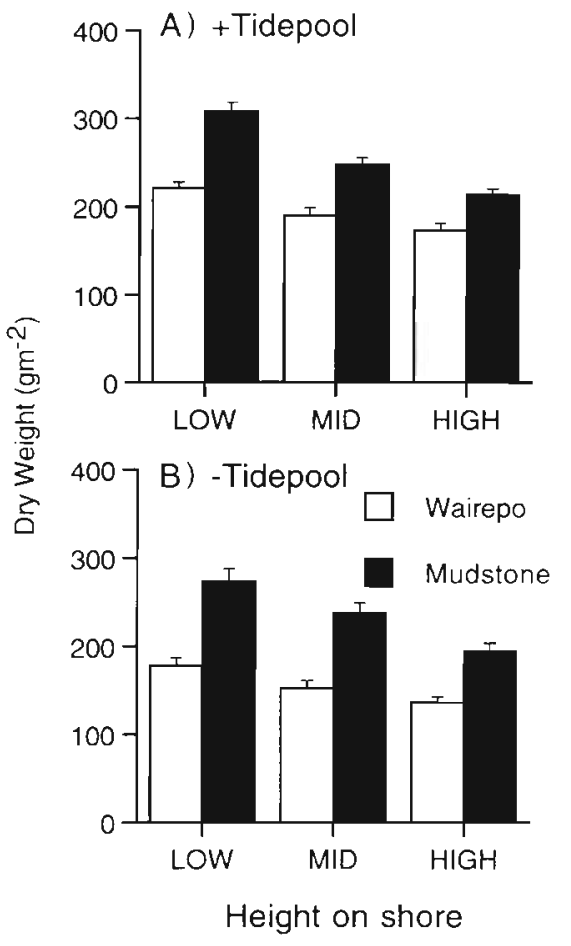

Fig. 9. Zostera novazelandica. Mean ( $+1 \mathrm{SE})$ total dry weight of plants at 3 shore heights from patches (A) associated and (B) not associated with tidepools at Wairepo Flats (open bars) and Mudstone Bay (closed bars)
The total plant biomass per area also varied across all factors (Fig. 9). It was significantly greater at Mudstone Bay than at Wairepo Flats $\left(F_{1,24}=2039, \mathrm{p}<0.001\right)$ and varied with tidal height $\left(F_{2,24}=593, \mathrm{p}<0.001\right)$. Patches associated with tidepools had a greater biomass per unit area than did those not associated with tidepools $\left(F_{1,24}=359, p<0.001\right)$. At both sites, the greatest biomass was found on the low shore in patches associated with tidepools. Patch biomass per unit area and the leaf area index (LAI) varied seasonally (Fig. 10). Both the LAI and biomass decreased from March to July and recovered during the spring to reach a summer maximum. The proportion of above-ground biomass to below-ground biomass was lowest during winter at both sites (16\%). The biomass of reproductive shoots accounted for a maximum of $4.4 \%$ of total plant biomass during the summer at Wairepo Flats, and $6.4 \%$ at Mudstone Bay. The ratio of above-ground to below-ground biomass was similar between sites $\left(F_{1,20}=3.63, \mathrm{p}=0.06\right)$.
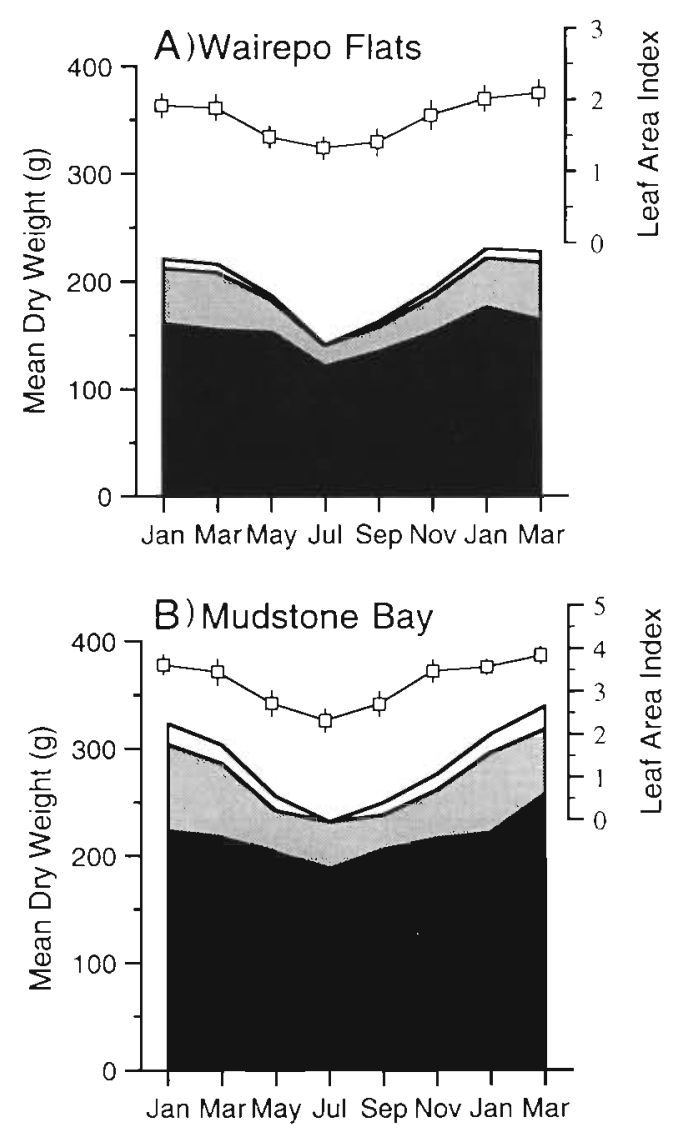

Fig. 10. Zostera novazelandica. Mean dry weight of three $50 \mathrm{~cm}^{2}$ core samples taken from patches on the low shore at (A) Wairepo Flats and (B) Mudstone Bay each month. Total biomass is divided into below-ground (root/rhizome, black area), vegetative (shaded area) and reproductive (white area) components. Mean ( \pm 1 SE) leaf area indices for each month are also shown 

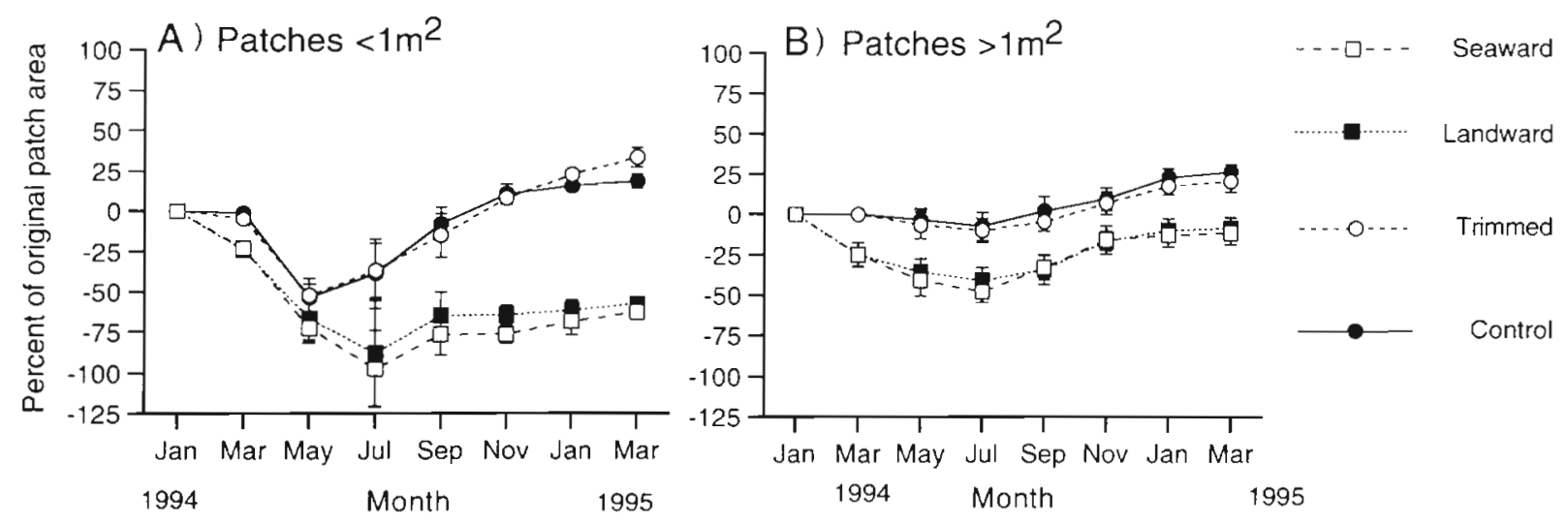

Fig. 11. Zostera novazelandica. Mean percent change $( \pm 1 \mathrm{SE})$ in patch size through time in experimentally disturbed $(25 \%$ of patch removed on either landward or seaward side), trimmed and control patches in 2 size classes: $(A)<1 \mathrm{~m}^{2}$, and $(B)>1 \mathrm{~m}^{2}$ initial surface area

\section{Patch disturbance}

The experimental patches showed significantly different changes throughout the year $\left(F_{5,28}=77.67, \mathrm{p}<\right.$ $0.001)$, among treatments $\left(F_{3,32}=16.84, \mathrm{p}<0.001\right)$ and between patch sizes $\left(F_{1,32}=32.38, \mathrm{p}<0.001\right)$. Treatment effects did not depend on patch size ( $\mathrm{T} \times \mathrm{P}: F_{3,32}=0.92$, $p=0.443)$. However, the treatment effects varied among the months of sampling ( $I \times$ Month: $F_{15,77}=2.16$, $\mathrm{p}=0.015$ ) and the 2 sizes of experimental patches showed different responses among months (Size $x$ Month: $F_{5,28}=2.62, \mathrm{p}=0.046$ ). The greatest effects were in the disturbed patches, from which $25 \%$ of the surface area was removed from either the landward or seaward side during January 1994 (Fig. 11A). Although there was a decline in the sizes of all patches $<1 \mathrm{~m}^{2}$, including the controls, from March to May, the disturbed patches continued to lose area through July. There was little difference between patches disturbed on the landward or seaward edge, but both of these treatments had greater changes and less recovery than the controls and trimmed patches. By March 1995, the disturbed patches $<1 \mathrm{~m}^{2}$ showed little recovery and were ca. $42 \%$ smaller than their experimentally altered sizes 1 yr earlier. Control patches, however, slightly exceeded their original sizes by March 1995.

The percentage decrease of patches $>1 \mathrm{~m}^{2}$ was much less than for the small patches (Fig. $11 \mathrm{~B}$ ). There was a decline of the disturbed patches in winter, but these recovered to slightly more than their experimentally altered sizes by March 1995.

Patches that had $90 \%$ of their surface foliage trimmed in January 1994 were similar to controls. There was an effect of patch size in that both the trimmed and control small patches decreased in winter while the large patches remained about the same. By
March 1995, both the small and large trimmed patches were $>20 \%$ larger than their original sizes.

Mortality occurred only in the smaller size class $\left(<1 \mathrm{~m}^{2}\right)$ and mostly in the disturbed patches, but its magnitude depended on the position of the disturbance. Forty percent of the landward-disturbed patches and $20 \%$ of the seaward-disturbed patches were lost during the experiment, compared to $5 \%$ of controls, all of them during the winter months. No other patch mortality occurred in this experiment.

The density of ramets in disturbed patches was on average around $35 \%$ lower than in the controls (Fig. 12). Trimmed patches, however, had about $40 \%$ greater ramet density than controls. It is clear that damage to the rhizomes, as in the seaward and landward disturbance treatments, had long-term consequences on the production of above-ground biomass of the entire patches while trimming of blades stimulated new growth.

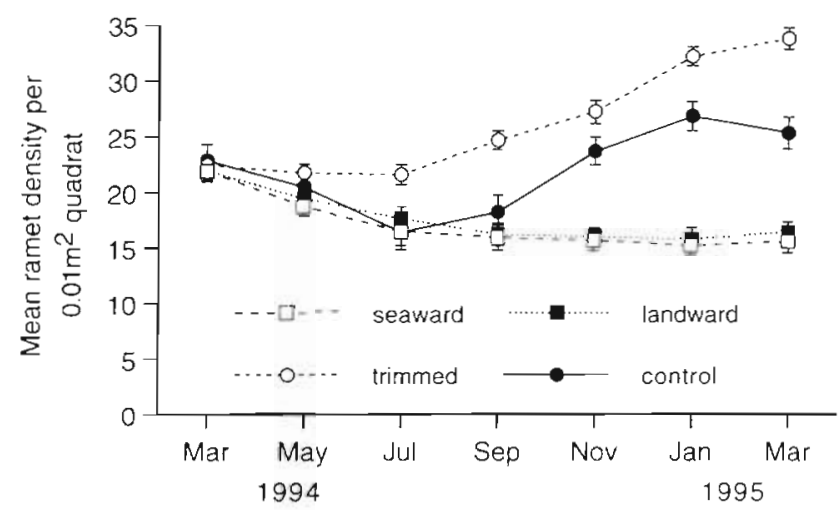

Fig. 12, Zostera novazelandica. Mean ramet density per $0.01 \mathrm{~m}^{2}( \pm 1 \mathrm{SE}$ ) in experimentally disturbed (either landward or seaward side), trimmed and control patches (both patch sizes combined) from March 1994 to March 1995 


\section{DISCUSSION}

Most Zostera novazelandica patches on the reefs around the Kaikoura Peninsula occur in the mid and low intertidal zones and have a total surface area less than $1 \mathrm{~m}^{2}$. This pattern appears to be typical of shallow seagrasses (Duarte \& Sand-Jensen 1990a, Olesen \& Sand-Jensen 1994a, Vidondo et al. 1997), and is indicative of rapid patch formation and mortality (Olesen \& Sand-Jensen 1994a, Vidondo et al. 1997). During winter months most patches decreased in size. Patch mortality was greatest during winter and spring as newly germinated seedlings and small patches suffered severe erosion at both study sites and were removed by storms. Severe storms are most frequent during this time of year and the disappearance of patches coincides with them (cf. Mellors et al. 1993). Furthermore, it was common to see partially lifted patches that were later removed, as well as patches up to around $0.3 \mathrm{~m}^{2}$ that had been ripped off the reef and were strewn onto other habitats such as the algal beds nearby. The early colonisation phase of submerged macrophyte seedlings is characterised by high mortality rates in several species including Cymodocea nodosa (Duarte \& Sand-Jensen 1990a,b) and Z. marina (Olesen \& Sand-Jensen 1994a). These studies support the notion of a minimum patch size above which the likelihood of patch mortality decreases (Duarte \& Sand-Jensen 1990a,b, Sand-Jensen \& Madsen 1992, Olesen \& SandJensen 1994a), although even large patches can disappear during severe storms (Orth \& Moore 1983, den Hartog 1987). The lower mortalities of large patches may be attributed to improved anchoring and mutual physical protection among shoots (Vidondo et al. 1997). Olesen \& Sand-Jensen (1994a) found that mortality declined sharply with patch size and was restricted to patches with less than 32 shoots. Our results indicate that mortality on the Kaikoura Peninsula is confined almost entirely to patches less than $0.4 \mathrm{~m}^{2}$, or approximately 800 shoots.

New patches were formed from July to September either by the germination of seeds produced the previous summer or by the fragmentation of established patches into 2 or more smaller units. However, during the 14 mo of this study seedlings made only a shortterm contribution to increasing the number of patches at both sites. Few seedlings recruited and none of these survived for more than a few months. Most of the small patches present at the start of the study survived, but were about the same size after 1 yr. This suggests that successful recruitment from seedlings is either episodic or else occurs at very low levels. This pattern is common in perennial seagrasses, which rely primarily on vegetative growth for the maintenance and expansion of beds (Harrison 1979, Phillips et al. 1983,
Keddy 1987. Williams 1990). We observed that the recruitment of seedlings occurred only in tide pools or cracks and was mostly associated with turfing coralline algae, which accumulate sediment and provide a suitable substratum for seed germination. Seedlings of several species that recruit into the intertidal environment have very low survival rates due to the highly variable conditions (Harrison 1979). For Zostera novazelandica, there was an overall decrease in the number of patches in the permanent plots at both sites from January 1994 to March 1995, but the natural expansion of established patches maintained a relatively constant coverage over the study period. Rapid turnover of small patches and low seedling survival has also been observed in intertidal $Z$, marina (Olesen \& Sand-Jensen $1994 \mathrm{C}$ ).

The structural integrity of patches was altered during the colder months, resulting in the general deterioration of patches regardless of size. Overall environmental conditions can be severe during winter and early spring when there is a large influx of fresh water run-off due to rain over these intertidal platforms, coupled with reduced irradiance and water temperature (cf. Marbà et al. 1996b) and occasional storm waves several metres high. Wind stress is more likely to occur at low tide during summer when warm winds occur almost daily. There was no evidence that the magnitude of sediment loss was related to the tidal height of patches, and we saw no differences between the study sites.

Patches expanded between July and January but there was no significant size-specific growth rate of patches. Those associated with tidepools remained about the same size over the study period, while patches not associated with tidepools tended to decrease in size. The lateral growth of rhizomes may have facilitated the accumulation of sediment in pools. This is in agreement with the findings of Kentula \& McIntire (1986) and McMillan (1978), who found that the accumulation of biomass is influenced by the duration of water coverage in intertidal populations of Zostera marina. Plants that remained in pools at low tide were larger and appeared healthier than those left exposed between tides (Kentula \& McIntire 1986). Our comparisons of total dry weights between shore heights and patches associated and not associated with tidepools indicate that $Z$. novazelandica plants have greater productivity and biomass accumulation when in constant contact with water. Furthermore, because large patches are invariably in contact with tidepools and water-filled crevices, the ability of patches to expand beyond $1 \mathrm{~m}^{2}$ is largely dependent on the duration of immersion.

The temporal growth pattern of total biomass, biomass of leaves, flowers and biomass of roots and rhi- 
zomes of Zostera novazelandica (Ramage \& Schiel 1998) show the same unimodal seasonal curves reported for $Z$. noltii (Vermaat et al. 1987, PérezLloréns \& Niell 1993), Z. marina (McRoy 1970, SandJensen 1975, Jacobs 1979, Nienhuis \& De Bree 1980), and Thalassia testudinum (Lee \& Dunton 1996) although this can vary considerably among years (Marbà et al. 1996a, Mellors et al. 1993). Total biomass increases concurrently with the production of reproductive shoots (Kraemer \& Alberte 1993) and is associated with increased temperature and irradiance (Dunton 1994, Lee \& Dunton 1996). Variability in seasonal biomass is usually due to changes in shoot and leaf size rather than ramet density ( Lovett Doust 1981, Olesen \& Sand-Jensen 1994a,b, Fonseca et al. 1996). This is reflected in the higher LAI values during the summer and for plants low on the shore or in tidepools on the Kaikoura Peninsula (cf. Jacobs 1979, Aioi 1980, Kentula \& McIntire 1986). LAI values of 2.09 to $3.95 \mathrm{calcu}$ lated for $Z$. novazelandica plants low on the shore are comparable to those given by Kentula \& McIntire (1986) for $Z$. marina of 3.8 to 5.5. The patches in Kaikoura showed marked variability in ramet density between seasons, which compounds the effect of higher leaf surface area on biomass during the summer (McRoy 1970, Kentula \& McIntire 1986). In comparison, rhizome biomass remains relatively constant throughout the year (Lee \& Dunton 1996, Ramage \& Schiel 1998).

Decreases in seagrass abundance can be caused by a variety of abiotic (e.g. light intensity, wave action) and biotic (e.g. herbivory, bioturbation) factors (Valentine et al. 1994). Disturbance to Zostera novazelandica patches in the form of removal of an edge resulted in continued patch deterioration over several months. The proportional loss of area was particularly large for patches $<1 \mathrm{~m}^{2}$. After the experimental removal of $25 \%$ of their surface area, these small patches lost a further $70 \%$ of their original cover and recovered only to less than $40 \%$ of their pre-disturbance area after 14 mo. Large patches $\left(>1 \mathrm{~m}^{2}\right)$ were much more resilient to disturbance. Although reducing to around $50 \%$ of their original cover a few months after experimental trimming by $25 \%$, they recovered to around $80 \%$ of their pre-disturbed area after 1 yr. There was no difference between recovery growth rates of patches disturbed on their landward and seaward edges, an unexpected result given that patches usually appear healthier on the landward side and might have been expected to recover better from physical disturbance. The scouring action of waves usually erodes the seaward side of seagrass meadows while sediment accretion occurs on the landward side (Fonseca \& Kenworthy 1987). It seems likely that the severity of the experimental disturbance impaired the recovery of the dense healthy plants on the landward edges and the disturbance to the rhizome mat increased the likelihood of patches being removed from the reef through general deterioration and wave action. The deterioration of patches may have been exacerbated by interactions with the crab Macrophthalmus hirtipes, which burrows into the sediments of patches, particularly along edges that border tidepools, and feeds on seagrass rhizomes (Woods \& Schiel 1997). Other studies have shown that disturbance can affect patch survival. For example, Marbà \& Duarte (1995) found that the patchy distribution of Cymodocea nodosa within a bay was due to the disturbance caused by sand migrating over plants. Although plants could sustain some burial, patch mortality resulted from erosion as large dunes moved past seagrass patches. Marbà \& Duarte (1995) concluded that seagrass landscapes are regulated by the specific amplitudes and frequencies of disturbance events in different environments. Tidal and current flow, and wind-generated waves contribute to high variability in the shape and structure of seagrass beds (Robbins \& Bell 1994). The integration of information relating to the fluid motion effects on seagrass beds would no doubt aid in our understanding of seagrass ecology (Fonseca \& Kenworthy 1987).

The loss of photosynthetic tissue in Zostera novazelandica does not have any significant negative effect on patch expansion. Recovery of the trimmed patches was in agreement with findings that the significant portion of total plant biomass is below ground, which acts as a nutrient store and rapidly produces new shoots in response to trimming (Sohn \& Policansky 1977, Valentine et al. 1997). The enhanced ramet density in trimmed patches is typical of plants that experience infrequent but severe damage (Grime 1979). The ability to respond to defoliation either by renewed growth of severed leaves or by the development of new shoots results in a dense, rapidly repaired leaf canopy being formed (Grime 1979). Several studies of terrestrial plant systems have found that moderate levels of grazing can stimulate above-ground productivity by increasing shoot growth rates and the number of shoots produced (Belsky 1986). Cropping experiments on the seagrass Halodule wrightii by Mitchell (1987) demonstrated that trimming the ramets stimulated the production of new ramets, and that the most severely cropped plants had the greatest increase in ramet numbers. Like Halodule wrightii, $Z$. novazelandica grows by basal elongation of the meristemic region (Kuo \& McComb 1989), and ramets react to cropping by producing new ramets (Mitchell 1987). Grazing of Thalassia testudinum by sea urchins has been shown to have no negative effect on seagrass biomass due to a compensatory increase in the number of short shoots during the growing season (Valentine et al. 1997). 
In conclusion, the rate of patch expansion and contraction is regulated by physical factors on the intertidal platforms of Kaikoura. Winter storms affect patch margins, resulting in patches of all sizes at all shore heights decreasing in surface area. This is compounded by reduced plant growth (i.e. decreased leat length, number of leaves and ramet density) associated with lower water temperature and decreased irradiance. Effects on patches are exacerbated if they are physically disturbed, which causes increases in sediment loss and patch mortality. Recovery of patches in the warmer months is stimulated by greater vegetative growth of rhizomes and shoot density as environmental conditions, primarily light intensity and photoperiod, improve.

Over the 14 mo of this study, there was little change in the overall coverage of seagrass in the intertidal zone. Most of the dynamic processes in the population occurred in the smallest patches and no successful recruitment from seedlings was seen over the several hundred square meters of reef examined each month. Once patches reach around $0.4 \mathrm{~m}^{2}$, it appears they are long-lived. However, studies over at least several years are required to understand more completely the population dynamics of Zostera novazelandica.

Acknowledgements. We thank C. Ramage and J. van Berkel for logistic help and support, Dr L. Field for help with computer software and 3 anonymous referees for constructive criticism and significant help in improving this paper. We gratefully acknowledge the financial support of the Foundation of Research, Science and Technology, Grants UOC318, UOC412 and UOC511.

\section{LITERATURE CITED}

Aioi K (1980) Seasonal change in the standing crop of eelgrass (Zostera marina L.) in Odawa Bay, Central Japan. Aquat Bot 8:343-354

Bell SS, Hall MO, Robbins BD (1995) Towards a landscape approach in seagrass beds: using macroalgal accumulation to address questions of scale. Oecologia 104:163-168

Belsky AJ (1986) Does herbivory benefit plants? A review of the evidence. Am Nat 127:870-892

Cambridge ML (1975) Seagrasses of southwestern Australia with special reference to the ecology of Posidonia australis Hook in a polluted environment. Aquat Bot 1:149-161

Cambridge MI, McComb AJ (1984) The loss of seagrasses in Cockburn Sound, Western Australia. 1. The time course and magnitude of seagrass decline in relation to industrial development. Aquat Bot 20:229-243

Clarke SM, Kirkman H (1989) Seagrass dynamics. In: Larkum AWD, McComb AJ, Shepherd SA (eds) Biology of seagrasses. Elsevier Science Publishers, New York p 304-345

Dawson FH (1976) The annual production of the aquatic macrophyte Ranunculus penicillatus var. calcareus (RW Butcher) CDK Cook. Aquat Bot 2:51-73

den Hartog C (1970) The seagrasses of the world. North-Holland Publishing $\mathrm{Co}_{0}$ Amsterdam den Hartog C (1987) 'Wasting disease' and other dynamic phenomena in Zostera beds. Aquat Bot 27:3-14

Duarte CM, Sand-Jensen K (1990a) Seagrass colonization patch formation and patch growth in Cymodocea nodosa. Mar Ecol Prog Ser 65:193-200

Duarte CM, Sand-Jensen K (1990b) Seagrass colonization: biomass development and shoot demography in Cymodocea nodosa patches. Mar Ecol Prog Ser 67:97-103

Dunton KH (1994) Seasonal growth and biomass of the subtropical seagrass Halodule wrightii in relation to continuous measurements of underwater irradiance. Mar Biol 120:479-489

Evans GC (1972) The quantitative analysis of plant growth Blackwell Scientific Publications, London

Fonseca MS, Kenworthy WJ (1987) Effects of current on photosynthesis and distribution of seagrasses. Aquat Bot 27:59-78

Fonseca MS, Zieman JC, Thayer GW, Fisher JS (1983) The role of current velocity in structuring seagrass meadows. Estuar Coast Shelf Sci 17:367-380

Fonseca MS, Kenworthy WJ, Courtney FX (1996) Development of planted seagrass beds in Tampa Bay, Florida, USA. I. Plant components. Mar Ecol Prog Ser 132:127-139

Grime JP (1979) Plant strategies and vegetation processes. John Wiley \& Sons Ltd, Bath

Harrison PG (1979) Reproductive strategies in intertidal populations of two co-occurring seagrasses (Zostera spp.). Can J Bot 57:263-268

Hickford MJH, Schiel DR (1995) Catch vs count: effects of gill-netting on reef fish populations in southern New Zealand. J Exp Mar Biol Ecol 188:215-232

Jacobs RPWM (1979) Distribution and aspects of the production and biomass of eelgrass Zostera marina L., at Roscoff, France. Aquat Bot 7:151-172

Keddy CJ (1987) Reproduction of annual eelgrass: variation among habitats and comparison with perennial eelgrass (Zostera marina L.). Aquat Bot 27:243-256

Kemp WM, Twilley RR, Stevenson JC, Boynton WR, Means JC (1983) The decline of submerged vascular plants in upper Chesapeake Bay: summary of results concerning possible causes. J Mar Technol Soc 17:78-87

Kentula ME, McIntire CD (1986) The autecology and production dynamics of eelgrass (Zostera marina L.) in Netarts Bay, Oregon. Estuaries 9:188-199

Kirkman H (1978) The decline of seagrasses in northern areas of Moreton Bay, Queensland. Aquat Bot 5:63-76

Kotliar NB, Wiens JA (1990) Multiple scales of patchiness and patch structure: a hierarchical framework for the study of heterogeneity. Oikos 59:253-260

Kraemer GP, Alberte RS (1993) Age-related patterns of metabolism and biomass in subterranean tissues of Zostera marina (eelgrass). Mar Ecol Prog Ser 95:193-203

Kuo J, McComb AJ (1989) Seagrass taxonomy, structure and development. In: Larkum AWD, McComb AJ, Shepherd, SA (eds) Biology of seagrasses. Elsevier Science Publishers, New York, p 6-73

Larkum AWD. West RJ (1983) Stability, depletion and restoration of seagrass beds. Proc Linn Soc NSW 106:201-212

Larkum AWD, Collett LC, Williams RJ (1984) The standing stock, growth and shoot production of Zostera capricorni Aschers, in Botany Bay, New South Wales, Australia. Aquat Bot 19:307-327

Lee KS, Dunton KH (1996) Production and carbon reserve dynamics of the seagrass Thalassia testudinum in Corpus Christi Bay, Texas, USA. Mar Ecol Prog Ser 143:201-210

Levin SA, Paine RT (1974) Disturbance, patch formation and community structure. Proc Natl Acad Sci (USA) 71. $2744-2747$ 
Levin SA, Powell TM, Steele JH (1993) Patch dynamics. Lecture notes in biomathematics 96. Springer-Verlag, Berlin

Lovett Doust L (1981) Population dynamics and local specialization in a clonal perennial (Ranunculus repens) I. The dynamics of ramets in contrasting habitats. J Ecol 69: $743-755$

Marbà N, Duarte CM (1995) Coupling of seagrass (Cymodacea nodosa) patch dynamics to subaqueous dune migration. J Ecol 83:381-389

Marbà N, Duarte CM, Cebrián J, Gallegos ME, Olesen B, Sand-Jensen K (1996a) Growth and population dynamics of Posidonia oceanica on the Spanish Mediterranean coast: elucidating seagrass decline. Mar Ecol Prog Ser 137: 203-213

Marbà N, Cebrián J, Enríques S, Duarte CM (1996b) Growth patterns of Western Mediterranean seagrasses: speciesspecific responses to seasonal forcing. Mar Ecol Prog Ser 133:203-215

McComb AJ, Cambridge ML, Kirkman H, Kuo J (1981) The biology of Australian seagrasses. In: Pate JS, McComb AJ (eds) Biology of Australian plants. University of Western Australia Press, Perth

McMillan C (1978) Morphogeographic variation under controlled conditions in five seagrasses, Thalassia testudinum, Halodule wrightii, Syringodium filiforme, Halophila engelmannii and Zostera marina. Aquat Bot 4: 169-189

McRoy CP (1970) Standing stocks and other features of eelgrass (Zostera marina) populations on the Coast of Alaska. J Fish Res Bd Can 27:1811-1821

Mellors JE, Marsh H, Coles RG (1993) Intra-annual changes in seagrass standing crop, Green Island, northern Queensland. Aust J Mar Freshw Res 44:33-41

Mitchell CA (1987) Growth of Halodule wrightii in culture and the effects of cropping, light, salinity and atrazine Aquat Bot 28:25-37

Nienhuis PH, De Bree BHH (1980) Production and growth dynamics of eelgrass (Zostera marina) in brackish Lake Grevelingen (The Netherlands). Neth J Sea Res 14: $102-118$

Olesen B, Sand-Jensen K (1994a) Patch dynamics of eelgrass Zostera marina. Mar Ecol Prog Ser 106:147-156

Olesen B, Sand-Jensen K (1994b) Biomass-density patterns in the temperate seagrass Zostera marina. Mar Ecol Prog Ser 109:283-291

Olesen B, Sand-Jensen K (1994c) Demography of shallow eelgrass (Zostera marina) populations-shoot dynamics and biomass development. J Ecol 82:379-390

Orth RJ, Moore KA (1983) Chesapeake Bay: an unprecedented decline in submerged aquatic vegetation. Science 222:51-52

Paine RT (1979) Disaster, catastrophe, and local persistence of the sea palm Postelsia palmaeformis. Science 205: $685-686$

Paine RT, Levin SA (1981) Intertidal landscapes: disturbance and the dynamics of pattern. Ecol Monogr 51:145-178

Pérez-Lloréns JL, Niell FX (1993) Seasonal dynamics of biomass and nutrient content in the intertidal seagrass Zostera noltii Hornem. from the Palmones River estuary, Spain. Aquat Bot 46:49-66

Phillips RC, Grant WS, McRoy CP (1983) Reproductive strategies of eelgrass (Zostera marina L.). Aquat Bot 16:1-20
Ramage DL, Schiel DR (1998) Reproduction in the seagrass Zostera novazelandica on intertidal platforms in southern New Zealand. Mar Biol 130:479-489

Robbins BD, Bell SS (1994) Seagrass landscapes: a terrestrial approach to the marine subtidal environment. Trends Ecol Evol 9:301-303

Sand-Jensen K (1975) Biomass, net production and growth dynamics in an eelgrass (Zostera Marina) population in Vellerup Vig, Denmark. Ophelia 14:185-201

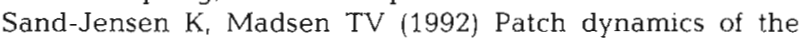
stream macrophyte, Callitriche cophocarpa. Freshw Biol $27: 277-282$

Short FT, Wyllie-Echeverria S (1996) Natural and humaninduced disturbances of seagrasses. Environ Conserv 23: $17-27$

Sohn JJ, Policansky D (1977) The costs of reproduction in the mayapple Podophyllum peltatum (Berberidaceae). Ecology 58:1366-1374

Sousa WP (1984) Intertidal mosaics: patch size, propagule availability, and spatially variable patterns of succession. Ecology 65:1918-1935

Steele JH, Carpenter SR, Cohen JE, Dayton PK, Ricklefs RE (1993) Comparing terrestrial and marine ecological systems. In: Levin SA, Powell TM, Steele JH (eds) Patch dynamics. Lecture notes in biomathematics 96 . SpringerVerlag, Berlin, p 1-11

Turner T (1985) Stability of rocky intertidal surfgrass beds: persistence, preemption and recovery. Ecology 66:83-92

Valentine JF, Heck KL, Harper P, Beck M (1994) Effects of bioturbation in controlling turtlegrass (Thalassia testudinum Banks ex König) abundance: evidence from field enclosures and observations in the Northern Gulf of Mexico. J Exp Mar Biol Ecol 178:181-192

Valentine JF, Heck KL, Busby J, Webb D (1997) Experimental evidence that herbivory increases shoot density and productivity in a subtropical turtlegrass (Thalassia testudinum) meadow. Oecologia 112:193-200

Vermaat JE, Hootsmans MJM, Nienhuis PH (1987) Seasonal dynamics and leaf growth of Zostera noltii Hornem., a perennial intertidal seagrass. Aquat Bot 28:287-299

Vermaat JE, Beijer JAJ, Gijlstra R, Hootsmans MJM, Philippart CJM, van den Brink NW, van Vierssen W (1993) Leaf dynamics and standing stocks of intertidal Zostera noltii (Hornem) and Cymodocea nodosa (Ucria) Ascherson on the Banc d'Arguin, Mauritania. Hydrobiol 248:59-72

Vidondo B, Duarte CM, Middelboe AL, Stefansen K, Lützen T, Nielsen SL (1997) Dynamics of a landscape mosaic: size and age distributions, growth and demography of seagrass Cymodocea nodosa patches. Mar Ecol Prog Ser 158: $131-138$

Williams SL (1990) Experimental studies on Caribbean seagrass bed development. Ecol Monogr 60:449-469

Woods CMC, Schiel DR (1997) Use of seagrass Zostera novazelandica (Setchell, 1933) as habitat and food by the crab Macrophthalmus hirtipes (Heller, 1862) (Brachyura: Ocypodidae) on rocky platforms in southern New Zealand. J Exp Mar Biol Ecol 214:49-65

Wu J, Levin SA (1994) A spatial patch dynamic modeling approach to patterns and process in an annual grassland. Ecol Monogr 64:447-464

Young PC, Kirkman $H$ (1975) The seagrass communities of Morton Bay, Queensland. Aquat Bot 1:191-202 